Received: 08.07.2010, Final Text: 09.11.11

Keywords: earthquake; shelter; temporary housing; privacy; conceptual design; user needs.

\section{AN ANALYSIS OF PHYSICAL AND PSYCHOLOGICAL EXPECTATIONS OF EARTHQUAKE VICTIMS FROM TEMPORARY SHELTERS: A DESIGN PROPOSAL Belma YÜKSEL, Deniz HASIRCI}

This study analyzes physical and psychological expectations of earthquake victims from temporary shelters and presents a design proposal. Interviews were conducted with earthquake victims in the city of Kocaeli in Turkey, and needs were identified. Also, user survey results from previous studies that have been conducted after the August 17th earthquake in 1999 were used to establish the design requirements for a temporary housing unit. While lack of space and issues of crowding, noise, and hygiene were mentioned as the most important problems in temporary earthquake shelters, suggestions to improve them included consideration of psychology and privacy needs of victims. The need for a "home" and not just a shelter has been identified and design guidelines have been examined.

\section{INTRODUCTION}

Privacy and psychological needs after an earthquake are very high, however these are rarely considered in temporary emergency earthquake shelters. As lack of space and privacy are added to hygiene problems and the victim's bereavement, it becomes even more difficult to cope with the effects of the disaster. Moreover, since a large number of people do not try to move out of temporary housing for quite long periods (Bütün, Dursun, and Vardareri 2005), and as temporary housing counts as a base for more permanent housing areas (Limoncu and Bayülgen, 2005), design solutions for temporary housing are quite valid and should be pursued.

Earthquakes can be very powerful causing psychological, economic and sociological destruction in communities. Earthquakes may occur at any time and can cause major damage, and returning back to normality can be difficult, thus learning to live with them has become inevitable (Coburn and Spence, 2002). The problem of housing is a primary need at this point. After the rescue operation and the removal of debris, one of the priorities is to create temporary settlement areas. Generally, tents are provided, until 
the completion of prefabricated permanent housing. Preparation is key to meeting the need for emergency and temporary housing. Manafpour (2003) also states that, research centers should be established in countries with high seismic risk to answer the country-specific issues with regard to earthquake hazard reduction.

On August the 17th, 1999, in Gölcük - Kocaeli in the Marmara Region of Turkey, an earthquake of 7.4 magnitude on the Richter scale occurred (Benko Ltd. Earthquake Information Centre, 2009; Coburn and Spence 2002). The earthquake killed 18,373 , injured 48,901 people, and damaged 285211 houses (96,796 houses being severely damaged), leaving approximately 800000 people homeless (Ban, 2001; Erdik, Biro and Durukal 2001; Hürriyet, 2000).

This earthquake was especially destructive to buildings, and thus the need for shelter and housing for the temporary disaster housing and living conditions were crucial. One of the most important problems faced in Turkey is that temporary housing is not often designed for pre-installation or an emergency situation. The specifications of buildings do not match user needs (Badri et al., 2006; Benko Ltd. Earthquake Information Centre, 2009; Halaç and Yamaçlı 2005; Limoncu and Bayülgen 2005). Moreover, especially in this earthquake, huge socio-psychological problems were discovered in all three phases "first aid phase", "rehabilitation phase", and "reconstruction phase" of the aid work (Limoncu and Bayülgen 2005).

The importance of shelter was obvious in the earthquakes that have occurred in Turkey in the last 15 years especially in Kocaeli (17 August 1999), Düzce (12 November 1999), İzmir-Urla (10 April 2003), and Hakkâri (25 January 2005) (Belgenet Archives, 2009), necessitating major revitalization work in these cities. The most destructive one was the one that took place in Kocaeli, Gölcük. The large amount of data collected by researchers after this earthquake has played an important role in this research study. Following this earthquake, after extensive investigation, the deficiencies in shelter design and use were identified by Baradan (2002) who identified a number of deficiencies in answering both the physical and psychological needs of families.

Ten years after this earthquake, which was considered significant in developing studies in earthquake housing, furniture capacity and material selections still remain inadequate, and seasonal changes are not sufficiently considered, especially for a 4-person family. Such deficiencies affect psychological needs such as privacy and comfort, resulting from trauma (Aytöre, 2005; Halaç and Yamaçlı 2005; Limoncu and Bayülgen 2005). Personal hygiene facilities are often not available within individual shelters, and technical support and isolation present huge problems in the installation stages. According to user surveys, these were specifically pointed out after the 17 August earthquake (Baradan, 2000).

In this study, problems regarding earthquake temporary housing are discussed, the required facilities are investigated, and a conceptual design is proposed in which these initial criteria are considered. The spaces in this proposal have been created to answer the physical and psychological needs of members of a family of four. Privacy is protected through the designation of separated areas, and the functionality of furniture is increased by its use in communal areas. Compact and adaptable kitchen furniture and cabinets aim to provide convenience, also bathrooms often located outside, is placed within the house. The primary purpose of this 
conceptual design proposal is to meet the individuals' basic needs in addition to creating awareness regarding the emergent need for a "home" instead of merely a shelter after an earthquake. A healthy recovery can only be ensured by providing for physical and psychological needs, and considering privacy requirements (Aytöre, 2005; Halaç and Yamaçlı 2005).

In Turkey where there is a $90 \%$ earthquake risk, there is a lack of studies on rapid and reliable housing options that answer various needs (Erdik, Biro, and Durukal, 2001). This present study would also be helpful for locations worldwide that share the same problem. This study aims to provide a conceptual design proposal that can be adapted to various situations.

\section{Description of the Study}

Earthquakes happen frequently in Turkey. One can observe the effects of a devastating earthquake at intervals of an average every four years. When earthquakes occur in regions where the population density is high, many lives are lost and much additional damage is caused (Coburn and Spence, 2002; Erdik, Biro and Durukal, 2001). Earthquakes leave tens of thousands homeless. The need for shelter is met by rapidly built temporary housing units constituting temporary settlement (Badri et al., 2006).

Additional damage is caused by rain, leading to floods, and gas leaks which often create fires. In these secondary disasters, temporary housing units frequently become dysfunctional, and the disaster-victims become homeless once again (Taşli, 2002). Many such problems like these occur in these temporary living areas, which are sometimes used for more than two years. Houses built after the Kocaeli earthquake, were only vacated in 2009, after ten years (Selvibayır, 2009; Yakut, 2004), thus becoming almost 'permanent'. This is due to poverty or the fact that tenants do not have a right for permanent housing after an earthquake.

It is therefore necessary to take essential action, and be prepared for new earthquakes in terms of housing. The "BoX in BoX Temporary House" project described in this study may be seen as a step towards a possible solution for temporary housing after earthquake periods. The main aims of this study are increased viability, a practical answer for user needs, identifying and coming closer to solving various housing problems, in addition to creating awareness for specialized design in this area.

\section{Methodology of the Study}

After an extensive literature review on disaster housing, this study describes design guidelines based on Baradan's (2000) interviews, conducted after the Kocaeli earthquake. The interviews conducted with earthquake experts and 56 people ( 28 female, and 28 male) in Kocaeli, Turkey, who had experienced earthquakes, and/or lived in temporary housing are also rendered in the research. The interview consists of 18 questions and three main parts: "personal information" (and experience with earthquake housing), "the design of earthquake housing", and "privacy" (See Appendix). SPSS 13 was used in the analysis. Appropriate design solutions and expectancies of users were investigated with 5- item Likert questionnaires, and three questions out of 18 were open ended.

Interviews were also conducted with prominent container companies in the Aegean Region, in addition to a detailed interview with the director of the "Earthquake Research and Application Centre" in İzmir, a city in Aegean Turkey where there is frequent seismic activity. The questions were about 
disasters, earthquakes in general and in the Aegean Region, the Aegean Region Graben system and land forms.

In this region, an earthquake of approximately 7 magnitude is expected in the near future (Habertürk, 2009), thus special attention should be given. The threshold for building damage in the Aegean region begins at 5.7 (Habertürk, 2009; İzmir Greater Municipality, 2000), and therefore a magnitude of 7 would cause destruction on a large scale in this area when one considers the fact that a number of buildings in the Northern part of the city are built on water logged land. Despite the specialized construction of these buildings, experts consider these buildings to be the most vulnerable (İzmir Greater Municipality, 2000).

The feasibility of "BoX in BoX Temporary House" as a proposal for temporary housing after earthquakes was assessed with the Earthquake Research and Application Centre and shelter companies. Construction drawings, details, materials, transportations, lighting layouts, bath furnishing, and drainage system were evaluated. The feedback was positive and suggested possible application.

\section{AID WORK AFTER EARTHQUAKES}

Earthquake victim aid studies are analyzed in three stages: "first aid phase", "rehabilitation phase", and "reconstruction phase" (Baradan, 2002: 12). The "first aid phase" includes removal of debris, saving lives, medical treatment, providing food, clothing, and shelter. This work can last from a few days to several weeks, and aims at the immediate preservation of life, provision of food and clothing, medical treatment and shelter needs within the shortest possible time period, and with optimum convenience. These activities are often carried out in tents (Özmen, 2003 and 2008; Yakut, 2004). The "rehabilitation phase" consists of the provision of vital services such as communication, transportation, water, electricity, sewage, education, and especially housing, in order to meet the minimum needs. This period continues until permanent housing is arranged according to standards such as, Eurocode 8 (Eurocodes, 2008). Finally, the "reconstruction phase" is the period that involves healing the wounds of the area, and bringing quality of life at least to the pre-disaster stage (Baradan, 2002; Yakut, 2004). This research study stands in the rehabilitation phase. Research has shown that $92 \%$ of Turkey falls within the earthquake zone (Deprem Dairesi Başkanlığı, 2011; Kayış, 2002), thus awareness of these stages are crucial for living with earthquakes. Within this framework, earthquake houses may be separated into two types, temporary and permanent. The design of temporary houses is especially important as these are the first spaces that provide a degree of normality after the disaster. Temporary earthquake houses should satisfy vital and functional needs for victims during the period of moving to permanent housing. The aim of these houses is to protect the family from outside dangers and create private spaces inside to protect their privacy and bring back feelings of security (Ergünay, 2000; Özmen, 2003 and 2008; Tanrisever et al., 2008).

\section{CRITERIA FOR TEMPORARY SHELTERS}

After earthquakes, since people suffer a complete break in the social, economic, and physical integrity of life, there is an urgent need for protection and shelter. Since temporary earthquake houses are the first places of contact for victims after their own houses have been demolished 
and because they generally occupy them for a minimum of two years, houses ought to be habitable for victims rather than only providing for basic needs (Acerer, 1999). User requests and period of use should be taken into consideration and they should meet victims' psychological and physiological permanent sheltering requirements, as well as being feasible (Yakut, 2004). Participation of potential users not only with regard to having a say in the shelter, but also in the design, planning and constructing of the shelters has been stated by Fallahi (2007) to contribute to pain relief and suffering.

On this account, the first aim of the temporary disaster housing design is to give a sense of 'home'. A minimum of $18.6 \mathrm{~m} 2$ and optimum of $30 \mathrm{~m} 2$ should be provided to ensure some privacy for each user (Ban, 2001). Privacy are the most important points when living in temporary earthquake houses. Although it is expected that temporary earthquake houses are built smaller than permanent earthquake houses, the minimum standards should be maintained as closely as possible (Bütün, Dursun, and Vardareri, 2005).

Temporary housing with minimum living conditions must involve spaces to live, sleep and socialize as well as areas for food preparation, personal hygiene, and privacy, although this last item is relatively difficult to achieve. The reason for this is, the relative difficulty of adequately answering the psychological need of privacy compared to a physical need such as a place for personal hygiene. Separate bedroom areas should be provided for children of different ages and gender to ensure healthy development, and to decrease possibility of trauma and increase the sense of belonging (Baradan, 2002; Özmen, 2003, 2008).

Creating a healthy environment is key for victims' comfort. Therefore, materials in shelters should be environmentally friendly and provide a sense of security. Additionally, climatic, visual and auditory comfort should be provided. Temporary housing for earthquakes should provide essential features such as protection from rain/damp, structural safety and ease of reassembly in a new location (Tanrisever et al., 2008).

The potential for building reuse is an important feature, and thus during assembly permanent ground contacts, such as concrete casting, which would make it impossible to use again should be avoided (Baradan, 2002). Ease of assembly, economics, and drainage are the three most significant issues regarding temporary housing. Temporary housing in the event of an earthquake should be installed as quickly as possible. Constructionmaterials, furnishings, equipment and tools should be ready or able to be prepared in a short time. Care should be taken that safe housing is built at a distance from the earthquake site, both to avoid the possibilities of aftershocks, and to remove victims from the visible effects of the disaster (Taşli, 2002).

Drainage is also often a critical problem in temporary housing. One of the problems users encounter is regarding the use of the toilets and waste. Leaking facilities frequently create serious health problems and disturbing odours. Waterless toilets are one of the best solutions for these problems (EPA, 1999). Fans such as the wall fan system can also be used for ventilation and to ensure adequate air circulation in the bathrooms. Wall fan systems can absorb fan vibrations and sound is kept to a minimum, they have a long life, are easy to install and consume little energy. Wall fans remove odours from bathroom and increase indoor air quality, and thus 
help protect users' health. Also, fans aid in removing moisture that may harm the structure, as they decrease humidity.

Considering the results of Baradan's (2002) interviews, temporary housing design should provide for all the needs of the typical victim. The most critical needs according to the interviews are:

- Housing that will benefit users, their socio-cultural and socioeconomic status, habits of life, and family structures.

- Housing that is produced within a short time.

- Infrastructure projects are currently under study and other related disciplines-mechanical-electrical employees come together and partners in decision making are required.

- Achieving the highest level of satisfaction regarding the provision of pedestrian sidewalk and street widths, security issues, layout aesthetics, aesthetics of the housing.

- Ensuring satisfactory social conditions (residential area, sociocultural structures, health structures, access to city centres, public buildings and the satisfaction of the public transport sub-conditions).

- Ensuring satisfactory housing plans in terms of household size, overall usability, usefulness of space, storage, and laundry and drying facilities.

Costs regarding temporary earthquake housing involve storage or production over the disaster area, transportation, the basic cost of excavation, foundation and set up, water, electricity, sewage, heating, the assembly of workers qualified for disaster relief, repair and maintenance, and disassembly. In large scale earthquakes, these costs may exceed the government budget, thus, efficient use of the earthquake budget, and the design of low-cost, sustainable, reusable housing is crucial (Hürriyet, 2008).

Adaptability and modularity are advantageous, as these features provide the opportunity for alteration according to need. While redeploying temporary earthquake housing, even in the same region, local and climactic conditions may be very different, thus, the house must be suitable for use in varying conditions; houses should be resistant to rain, snow, heat, cold and high humidity conditions, and should not need repair for at least two years (Kayış, 2002).

\section{FINDINGS}

Two groups of findings were used to guide the temporary housing conceptual design -findings from a previous survey of Baradan (2002) and the interviews conducted as part of this study.

\section{Findings from a Previous Survey}

The survey conducted by Baradan (2002) with victims living in their temporary shelters after the Kocaeli earthquake covers issues of general problems with the houses, satisfaction regarding size, heating, security, and neighbourhood quality. The results show a significant lack of satisfaction with security $(68 \%)$, due to the ignorance of persons in charge of security, such as management and guards. A majority of the respondents were living in 4-person houses, and thus this was effective on the decision to design the proposal accordingly. Almost $60 \%$ of the respondents had made an addition to the house after they moved in, due to lack of privacy and 
need for individualized spaces. This finding also affected the design of the specialized areas in the proposal. $96 \%$ of the respondents stated that, there were problems in the house related to weather and climate conditions, and $68 \%$ stated they had to do major repair. Stability and durability was believed to be one of the first topics that needed attention, as it contradicts greatly the house becoming a 'home'. The overall satisfaction with the temporary housing built in Kocaeli after the 1999 earthquake was 24\%, however, $70 \%$ stated that it was only better than a tent.

The purpose of the interviews conducted in this study, was to achieve a more in-depth understanding of these issues as well as relation to the significant topic of 'privacy'. Thus, questions related to 'privacy' and 'sense of belonging' were asked, and the relationships between these issues were analyzed.

\section{Findings from the Interviews}

In the open ended questions, respondents were asked about the biggest problem in earthquake housing, the most successful examples with reasons, and suggestions for improvements. The most crucial problems stated were these: lack of privacy; lack of a private life; lack of space; all family members forced to sleep in the same space; lack of opportunity to consider feelings of others, including fear, sadness and grief; the presence of mud, especially mud in the house; the weather conditions; the presence of public toilets and smells from those toilets; considerations for hygiene; toilets constantly being blocked; lack of water, including for laundry or dishwashing; heating, cooling, electricity problems; humidity, leakage of rainwater into the housing space; the presence of insects; lack of Windows; lack of sunlight in the houses; transportation to and from the earthquake housing location; difficulty of obtaining food; insufficient quantity of earthquake housing; and rust on the building components.

'Hygiene' is one of the recurring issues that came up in the interviews. Comments in the interviews include a need for separate hygienic spaces for taking baths, and not enough water for cleaning kitchenware. A victim states, "There are bugs we cannot get rid of. It's terrible". Several of the respondents mention mud and clogging toilets as recurring problems in temporary houses.

For the topic of 'heating', a respondent says, "It is always cold, and it is very difficult to heat these temporary shelters in cold weather". Another temporary house user states, "We are never warm in the winter time". From the answers, there is a very clear need for proper heating as well as insulation in temporary houses.

Regarding 'stability', in his answer to the questionnaire, a respondent states, "For a more stable house, it should be designed by taking into consideration users' needs, and for all seasons". Another temporary house resident says, "Rain water comes inside the house. This should be prevented". The temporary house in this case, does not come close to becoming a home, as it does not even answer the requirements of a shelter.

About 'privacy' issues, a recent victim of an earthquake, states, "The temporary house should actually be a 'home', so that we the victims can escape the 'earthquake psychology' and so that we will not feel like a stranger in a strange place". Another simply says, "We have no privacy!", as there is very limited space and noise coming from all around. The desire for prettier, more homely, and more colourful houses are also mentioned 
as a factor to help in helping victims' feeling of attachment and belonging to their temporary houses. Temporary housing seems to be lacking several qualities of homes that are significant at this stage for victims, such as windows, warmth, colour, and space. The problem of 'noise' also contributes greatly and negatively to the privacy of the residents of temporary houses. Sounds of crying people after an earthquake may lead to depression in others in neighbouring houses. One respondent has mentioned widespread psychological problems following earthquakes due to the noise problem. He says, "We go through panic attacks when there is no way to experience peace and quiet. This is a violation of privacy!".

The suggestions that were given for improvement of temporary houses included separate spaces for bathing, precautions against rain water and wind, more durable structure, appropriate for variations in weather. Furthermore, it was suggested that earthquake housing should be more like homes, with spaces that help victims survive the effects of the earthquakes, and generally be more pleasant, with more colourful and better chosen materials. There were also calls for consideration of location, more and larger units, the installation of radiators, better opportunities for transportation and communication, and low rise construction to minimize damage by aftershocks. Further suggestions included considering Turkish family life, the provision of clothes, blankets and pillows, and improvement in furniture, and more research into and better preparation for future earthquakes.

Findings were analyzed, and the most successful examples of earthquake housing mentioned were, the METU Prefabricated Earthquake Housing, Cumhuriyet Neighborhood Earthquake Housing, and Kullar Prefabricated Earthquake Housing. None of these examples are containers and all have been designed with regard for rehabilitation of family life after an earthquake. This again points to the urgency of the need for a fast return to normal living conditions.

Findings showed that gender and privacy considerations were related, $(\mathrm{R}=0,447, \mathrm{p}=0,001)$. On the other hand, age and privacy considerations were not related, and in the open-ended questions people of all ages stated that there was a lack of privacy $(\mathrm{R}=0,445, \mathrm{p}=0,001)$. Gender and belonging needs was found to be related $(\mathrm{R}=-0,756, \mathrm{p}=0,007)$. Belonging and personalization was found to be moderately related, $R=0,304, p=0,023$. Users' privacy needs and the opportunity to be alone were found to be related $(R=0,500, p<0,00)$.

Users' psychology in the house and privacy was found to be related $(R=0,589, p=0,00)$. Number of users in the house and privacy was found to be related $(R=0,633, p=0,042)$. Number of users in the house and consideration of psychology was found to be related $(R=0,441, p=0,058)$.

Opportunity for choices and the type of earthquake housing were found to be related $(\mathrm{R}=0,821, \mathrm{p}=0,00)$. While tents allowed very few opportunities for variability in the environment, prefabricated housing was able to provide these opportunities. However, opportunities in both were stated to be inadequate. The opportunity to be alone and the need for visual privacy was found to be related $(\mathrm{R}=0,501, \mathrm{p}=0,097)$. The opportunity to be alone and the number of people were found to be related $(\mathrm{R}=0,604, \mathrm{p}=0,019)$. Overall, 'privacy' issues and "the need to return to normal living conditions" stood out in the answers, and these were in keeping with Baradan's survey results in 2002. 
Figure 1. General View of the "BoX in BoX Temporary House."

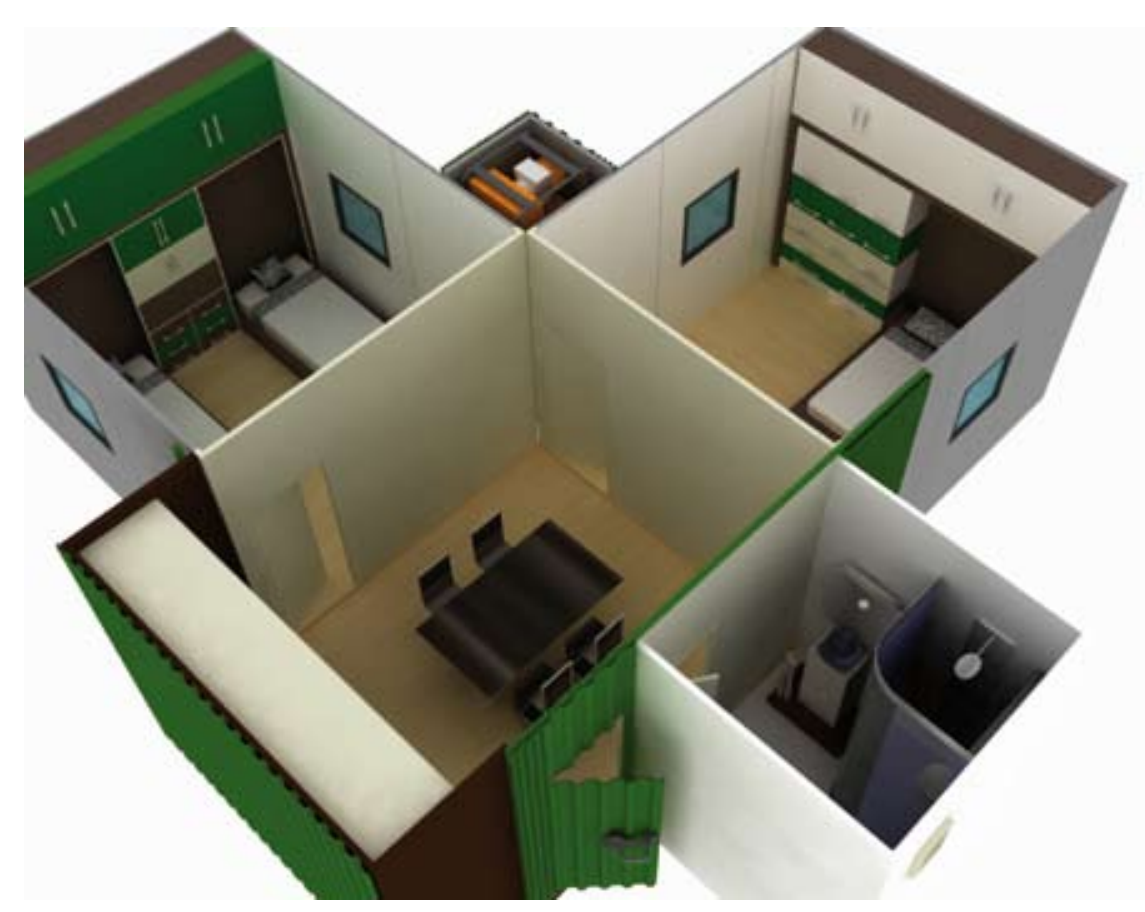

CONCEPTUAL DESIGN PROPOSAL

"BoX in BoX Temporary House"

The temporary earthquake house "BoX in BoX Temporary House" was developed considering the findings and the comments in the interviews. This house is a single unit that meets needs of users, and designed for a family of four (Figure 1). Special consideration has been given to the privacy needs of the members. The bedrooms, living room, kitchen, bathroom and toilet are listed as the users' basic needs. Ease of use in the organization of this space, electricity, drainage, ventilation and piping systems are also considered. Existing limitations of temporary earthquake housing and difficulties that are experienced by the users shape the design organization.

The interviews with victims of the Kocaeli earthquake point out that, in temporary housing, there is almost no privacy, there are equipment failures, material selections are inadequate, and that the insulation, ventilation, lighting and drainage systems are designed for a briefly used shelter (Baradan, 2002). Since victims can stay in these houses for more than a year, even two, it is important that these deficiencies are eliminated, and the shelter becomes a home to provide the security that a postearthquake victim needs.

The layout and material choice was designed taking into account production, use, and installation. Wet allocation spaces were separated as all sorts of leakage was given as one of the biggest problems, and one that triggered feelings of insecurity. The dimensions of the house are $4.4 \mathrm{~m} . \mathrm{x}$ $4.4 \mathrm{~m}$. with a total area of $19 \mathrm{~m} 2$. The form in its opened situation covers a total area of $36.90 \mathrm{~m} 2$. The layout plan consists of a living room, kitchen, children bedroom, double room and bathroom. A generator and water tank provide electricity and water requirements with a drainage balloon tank system. 
Figure 2. Exterior Framing and Opening of the "BoX in BoX Temporary House."
Figure 3. Interior Furnishing of the "BoX in BoX Temporary House."

Figure 4. Interior Furnishing of the "BoX in BoX Temporary House."
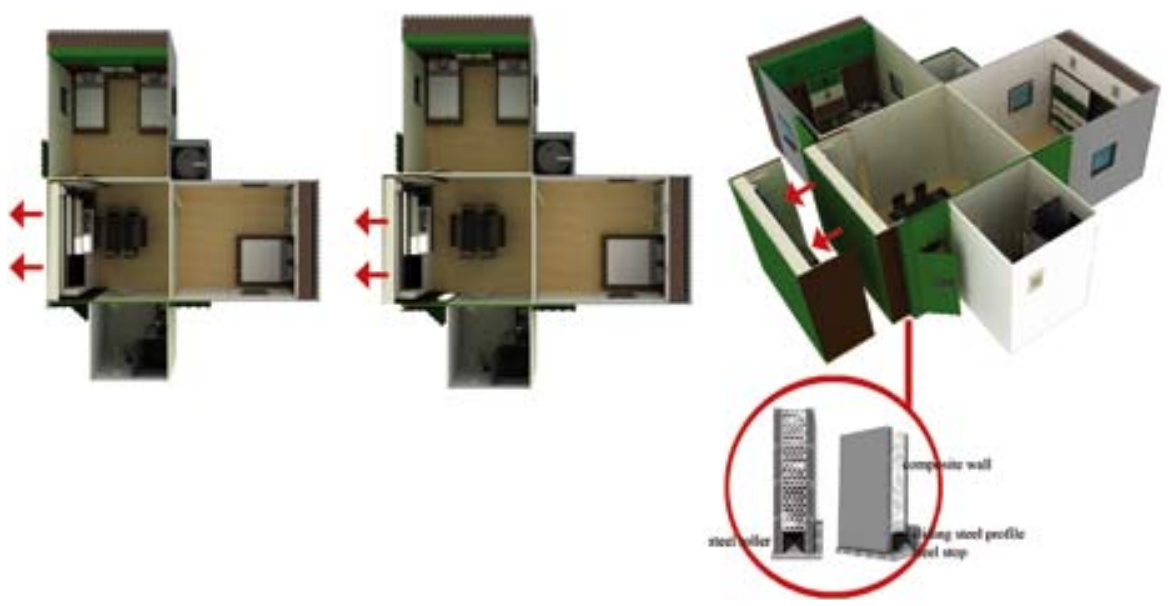

\section{Materials}

The exterior walls and roof are of galvanized sheets supported by a traverse element. External walls and roof are covered with composite wall materials. The composite walls consist of $1 \mathrm{~cm}$ polyester patterned sheet and $3 \mathrm{~cm}$ honeycomb tubes. To increase the impact of wall insulation, the honeycomb tubes in the application are made of foam silicone. $5 \mathrm{~cm}$. composite wall panels support the steel frames (Eşsiz, 2005; Terim, 2002).

A galvanized traverse painted sheet is used to prevent possible outside damage and additionally helps to support the general steel frame (Figure 2). Polyester sheets are used to create composite wall interiors and support the exterior frame. They sandwich the honeycomb tubes and silicone foam making a double layer, strengthening the walls and ensuring the rigidity of the honeycomb tubes. The honeycomb tubes are filled with silicone foam to help minimize insulation problems.

PVC cable ducts are used for electricity, and electrical equipment is concealed inside modules' ceilings and walls, or within each module within the house. The HVAC system is resolved with portable machines. This machine offers air conditioning in the house and provides all rooms with cooling and dehumidification.
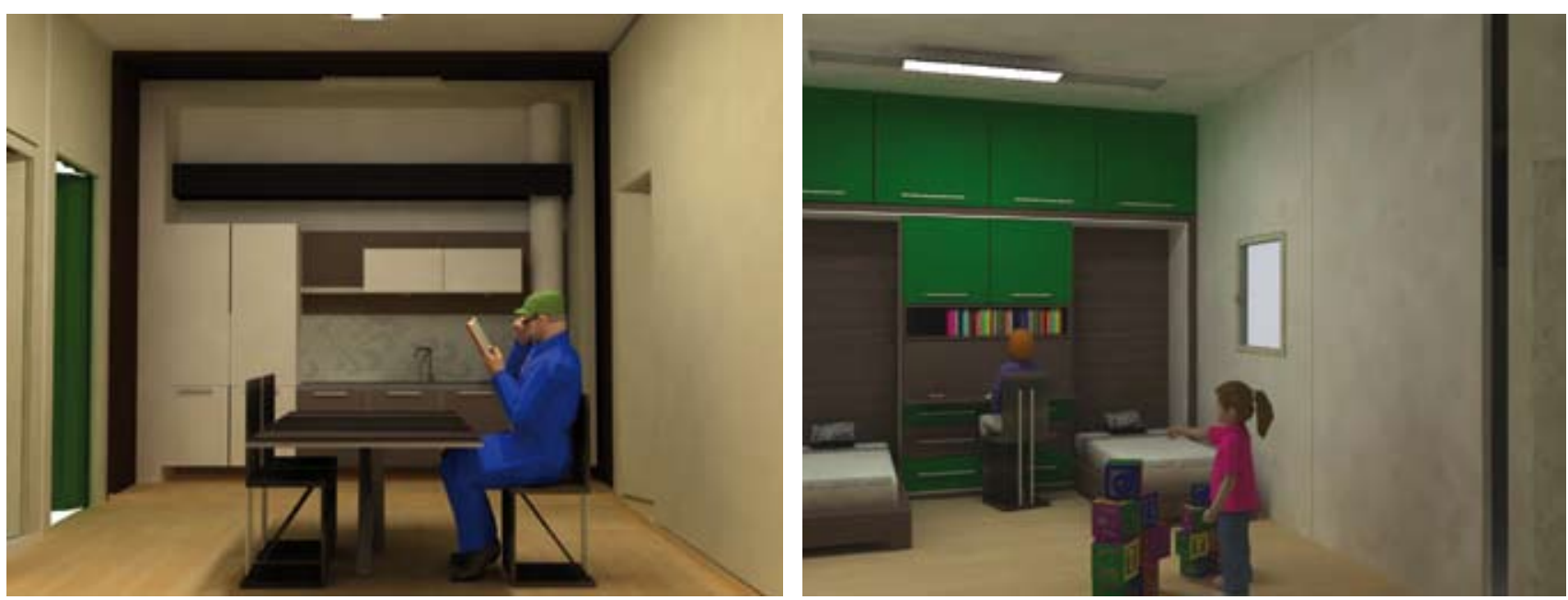


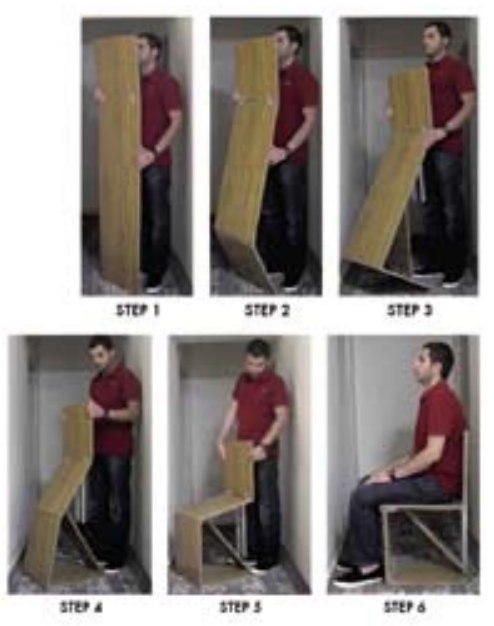

Figure 5. Living Room Chair Application Steps of the "BoX in BoX, Temporary House." Inspired by Dror Benshetrit's 'Pick Chair', 2006, accessed 15.01.2009, www.studiodror. com.

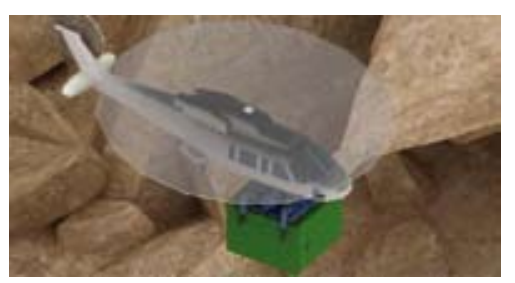

Figure 6. Transportation Step of the "BoX in BoX Temporary House."

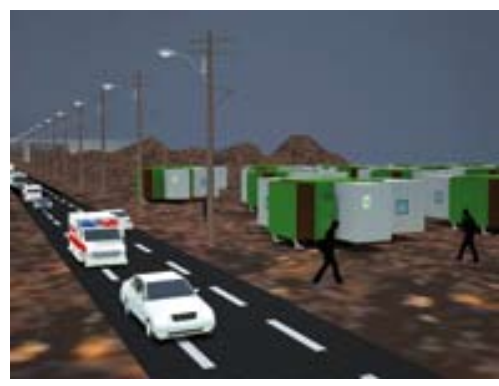

Figure 7. "BoX in BoX Temporary House" Settlement Area.

\section{Furniture}

The furniture should not be hazardous to health in any way, be durable and provide ease of installation and replacement (Aytöre, 2005). The furniture is designed to be adaptable, especially in the bedrooms and living room (Figure 3, 4). The bed and desk in the children's bedroom, and the bed, cabinets and drawers in the master bedroom are concealed inside furniture boxes, and this allows extra spaces in the room. Additionally, all cabinets and drawers are hidden in furniture boxes. This furniture boxes hold all furniture equipment that the user may need in the house. When beds are closed, the furniture box projects only $40 \mathrm{~cm}$ from the wall.

The furniture in the living room is hung on the wall when not used, saving space. The setting up of the chairs is simple. Setting up chairs is a simple process after removing them from the wall (Figure 5).

\section{Insulation and Noise}

Insulation problems in houses are also significant according to the interviews (Limoncu and Bayülgen, 2005). The silicone foam component in the composite wall is designed to provide advanced fire resisting properties and heat insulation. Silicone foam is ideal for heat insulation and fire prevention, with low flammability and is also thermally stable and water proof.

Noise is often a problem in temporary housing according to the interviews, thus it is important to promote privacy. Noise from people in nearby shelters may damage the sense of privacy, hindering the healing process. The honeycomb tubes which bring about composite wall structure are designed to provide superior sound isolation. Protection from external factors and seasonal changes should be taken into consideration, therefore, insulation to prevent water leakage inside the house is required both for physical and psychological health. Material selection and accurate details are critical for creating adequate water insulation. The groove pattern on the roof made of galvanized coated sheet material facilitates the flow of water off the roof. In addition, the temporary houses are designed with a raised floor, with no contact with the ground. This footing system allows adaptability to any type of land after brought by a helicopter (Figure 6, 7).

\section{Flooring}

A $10 \mathrm{~cm}$ steel profile in the ground strengthens the structure. In the upper and lower parts of the basement, $2.5 \mathrm{~cm}$ steel profiles are used. In the remaining $5 \mathrm{~cm}$ section, filled composite wall panels are used. The base of the wall panel is supported by steel profiles which increase the durability of the flooring and ceilings, additionally, preventing flexions. The interior flooring of the house is laminate, a quality material easily maintained over time.

\section{DISCUSSION AND CONCLUSION}

We cannot predict, prevent, or escape from earthquakes. Even with measures to reduce loss of life, it is difficult to minimize the effect of earthquakes, especially in developing countries. According to studies, privacy is one of the priority needs, and with minor adjustments to designs, this and other requirements may be met in a relatively easy and cost effective manner, considerably reducing the impact on earthquake victims (Badri et al., 2006). 
The article discussed the physical and psychological expectations of earthquake victims from temporary shelters. Investigations were carried out in Kocaeli with primarily affected persons from the earthquake. Privacy was found to be a significant element in temporary housing, affecting the rehabilitation of victims, however, it was seldom considered in temporary housing design. Gender, use of space, and psychology were all found to be related to privacy issues. Basic requirements such as heating, insulation, hygiene, and protection from weather conditions were found to be not just housing requirements, but also significant factors influencing recovery and rehabilitation in positive or negative ways. The conceptual design project was developed as an answer to post-earthquake shelter needs; planned for greater awareness and improvement of temporary housing. Moreover, extending the study to other earthquake regions and consulting victims aimed to guide the design of new projects, reveal variations in need across societies, and raise awareness on post-earthquake shelters.

Temporary housing built after earthquakes are often regarded as permanent by the users, and thus for the continuity of life and sustainability of the design, the relationship between people, equipment, and furniture schemes should be considered together. Moreover, this study seeks to enable designers to become more aware of the functional and psychological needs of earthquake victims, and thus more adequately to provide for those needs.

On the 8th of March, 2010, another destructive earthquake occurred in Okçular, Elazı ğ. The earthquake caught inhabitants in their sleep at 4.32 am killing about 60 , and injuring more than 70 people. The 5.9 magnitude temblor destroyed the traditionally built mud-brick houses and barns, blamed for the terrible consequences, in five villages. 230 tents were quickly set up in the area but did not help in keeping the cold weather conditions (of about $-5^{\circ} \mathrm{C}$ ) out. Ambulance helicopters, prefabricated homes, mobile kitchens were sent to the area, and rehabilitation units were established. The government is set to build earthquake-proof houses in the area in the coming weeks (Cumhuriyet, 2010; Özbilici and Fraser, 2010). On the 23rd of October, 2011, a 7.2 magnitude earthquake took place in Van. 596 people died, and 4152 people were injured as most buildings collapsed instantly. Surving people have moved to tents which are clearly not sufficient to hold out the cold and harsh weather conditions. Earthquakes will continue to take place in Turkey, but once again, there was a critical need of a quick and effective temporary housing solution for basic physical and psychological needs.

\section{ACKNOWLEDGMENTS}

The BoX in BoX design was created in the 'Visionary and Future Studies' course led by Asst. Prof. Dr. Markus Wilsing and Lecturer Didem Kan Kılıç (M.Des.) at İzmir University of Economics, Turkey, Department of Interior Architecture and Environmental Design. The development of the design proposal would not be possible without their significant contributions.

\section{REFERENCES}

ACERER, S. (1999) Afet Konutları Sorunu ve Deprem Örneğinde İncelenmesi (The Problems of Disaster Housing and Analysis from the Earthquake Perspective), unpublished Master's Thesis, İstanbul Technical University, İstanbul. 
AYTÖRE, S. (2005) Depolama ve Üretim Biçimleri Açılarından Seri Üretilen Mobilyaların Deprem Karşısında İnsan Üzerindeki Etkileri, Deprem Sempozyumu (Earthquake Symposium Proceedings), Kocaeli, 23-25 March, 2005; 1251-61.

BADRİ, S. A., ASGARY, A., EFTEKHARİ, A. R., LEVY, J. (2006) PostDisaster Resettlement, Development and Change: A Case Study of the 1990 Manjil Earthquake in Iran. Disasters, 30 (4) 451-68.

BAN, S. (2001) Paper Houses: Emergency Housing for Turkey, Earthquake Architecture,Tasarım Publishing Company, İstanbul; 62-6.

BARADAN, B. (2002) Geçici Afet Konutunun Yapım Sistemleri Açısından Incelenmesi (An Analysis of Temporary Disaster Housing According to Construction Systems), unpublished Master's Thesis, Dokuz Eylül University, İzmir.

BELGENET Archives (2009) Türkiye'deki Depremler (Earthquakes in Turkey), Available from; http://www.belgenet.com/deprem/depremt.html, accessed 16.04.09.

Benko Ltd. Earthquake Information Centre, 17 August Marmara EarthquakeAssessing Damages. http://www.benkoltd.com/deprem/deprem incele.htm, accessed 26.03.09.

BÜTÜN, H., G. DURSUN, VARDARERİ, D. (2005). Kocaeli Depremi ve İskân Problemi: Geçici Prefabriklerin Çözümsüzlü̆̆̈̈ ve Yoksulluğun Yeni Mekânı, Ekonometri Derneği, Kocaeli.

COBURN, A., SPENCE, R. (2002) Earthquake Protection, John Wiley and Sons., West Sussex.

Cumhuriyet (Newspaper) (2010) Kerpiç Depremi (Mud-brick earthquake); 9.3.2010.

Deprem Dairesi Başkanlığı, http://www.deprem.gov.tr/sarbis/Deprem/ DepremNedir.aspx\#KONU1, accessed May 2011.

ERDİK, M., BİRO,Y., DURUKAL, E. (2001) Assessments of Earthquake Hazard in

Turkey and Neighboring Regions, American Geophysical Union, Fall Meeting 2001. The Smithsonian/ NASA Astrophysics Data System.

ERGÜNAY, O. (2000) Afet Yönetimi Nedir? Nasıl Olmalıdır? Deprem Bölgelerinde Yapılaşma Sempozyumu (What is Disaster Management? How Should it Be? Symposium of Earthquake Region Planning). Conference Proceedings. DEU Mühendislik Fakültesi and ESBAS Publishing, İzmir.

EŞSİZ, Ö. (2005) Deprem Bölgelerindeki Yapılarda Çelik Çapraz Çerçeve Sistemlerinin Avantajlarl (Advantages of Steel Traverse Frame Systems in Structures in Earthquake Areas), Earthquake Symposium Proceedings 2005, Kocaeli University, Kocaeli; 665-8.

EUROCODES (2008) Institution of Civil Engineers (ICE) and Institution of Structural Engineers (Istructe) Initiative, http://www.eurocodes.co.uk/ Content.aspx? ContentId=1, accessed 09.06.09.

FALLAHI, A. (2007) Lessons Learned from the Housing Reconstruction Following the Bam Earthquake in Iran. The Australian Journal of Emergency Management, 22 (1) 26-35. 
Habertürk (2009) İzmir'de 7 Büyüklügüünde Deprem Bekleniyor (An Earthquake of 7 Magnitude is Expected in İzmir) 5.1.2009.

HALAÇ, H. H., YAMAÇLI, R. (2005) Tasarımda "Sağlamlık" ve Estetik Yaklaşımlar ("Durability" and Aesthetics in Design), Earthquake Symposium Proceedings, Kocaeli University, Kocaeli; 553-5.

Hürriyet (2000) 17 Ağustos 1999 Depreminin 1. Y1lı (The First Anniversary of the August 17th 1999 Earthquake).

Hürriyet (2008) Dünya Bankass ile ‘Deprem Maliyeti’ Zirvesi (Earthquake Meeting with the World Bank).

İzmir Greater Municipality (2000) İzmir Deprem Senaryosu ve Deprem Master Planı (İzmir Earthquake Scenario and Earthquake Master Plan), http://www.Izmir.bel.tr/Izmirdeprem/Izmirrapor.htm, accessed 31.08.09.

KAYIŞ, H. (2002) Kriz Durumlarında Acil Konut Üretimi ve Geçici Yerleşim Alanlarının Tasarım Kriterleri (Rapid House Production in Disaster Situations and Design Criteria of Temporary Settlements), Master's Thesis, Dokuz Eylül University, İzmir.

LIMONCU, S., BAYÜLGEN, C. (2005) Türkiye'de Afet Sonrası Yaşanan Barınma Sorunları (Shelter Problems in Turkey after Disasters). İstanbul: Faculty of Yildiz Technical University.

MANAFPOUR, A.R. (2003) The Bam, Iran Earthquake of 26 December 2003, Field Investigation Report prepared by Halcrow Group Limited, Earthquake Engineering Field Investigation Team, Halcrow Group Limited.

ÖZBİLİCI, B., FRASER, S. (2010) Okçular, Turkey, Associated Press Writers, Mon. Mar 8, 9:24 pm, ET.

ÖZMEN, B. (2003) Earthquake Risk Reduction Studies at General Directorate of Disaster Affairs, Forum on Regional Initiative for Disaster Risk Management, 2-4 March 2003, DEPAR Earthquake Research and Application Centre, Tehran, Iran; 1-16.

ÖZMEN, B. (2008) Türkiye Deprem Bölgeleri Haritası Nedir? Ve Nasıl Hazırlanır? (What is an Earthquake Regional Map? And How is it Prepared?), Sivil Savunma, n: 50 (193) 2-6.

SELVIBAYIR, N. (2009) Deprem Konutları Boşaltılıyor (Earthquake Houses Being Evacuated), Milliyet, 23.8.2009, İstanbul.

TANRISEVER, A.M., ŞAHIN, D., ARIKOL, N., KARACA, O. (2008) Deprem Eğitimi El Kitabı (Earthquake Education Handbook), Arıkol, G. (ed.), AKUT Kitaplığ 1 Yayın No: 4 İstanbul.

TAŞLI, D. (2002) A Research on Urgent and Temporary Shelters After Disasters, Unpublished Master's Thesis, Dokuz Eylül University, İzmir.

TERIM, B. (2002) A Study on "Temporary Post Disaster Housing Unit" Constructed With Light Gauge Steel Framing (LGSF) System, unpublished Master's Thesis, İzmir Institute of Technology, İzmir.

USGS (U.S. Geological Survey) (2009) Earthquake Hazards Program. Science For a Changing World. Turkey Earthquake Information, http:// earthquake.usgs.gov/ regional/world/?regionID $=22$, accessed 26.03.09. 
Alınd1: 08.07.2010; Son Metin: 09.11.2011

Anahtar Sözcükler: deprem; barınak; geçici konut; mahremiyet; kavramsal tasarım; kullanıcı gereksinimleri.
EPA - United States Environmental Protection, Office of Water Washington DC Agency (1999) Water Efficiency Technology Fact Sheet Composting Toilets, http://www.epa.gov/owm/mtb/comp.pdf, accessed 25.04.09.

YAKUT, I. (2004) Toplumun Deprem Tehlikesine Hazırlıkı Olması (Social Readiness for Earthquakes), Kocaeli Üniversitesi Yayınları, Kocaeli.

\section{DEPREM MAĞDURLARININ GEÇİCİ BARINAKLARDAN FİZIKSEL VE PSIKKOLOJIKK BEKLENTİSI: BİR TASARIM ÖNERİSI}

Bu çalışma, deprem mağdurlarının acil konutlardan fiziksel ve psikolojik beklentilerini incelemekte ve bir tasarım önerisi sunmaktadır. Kocaeli'nde deprem mağdurlarıyla görüşmeler yapılarak gereksinimler belirlenmiştir. Ayrıca 17 Ağustos 1999'da meydana gelen deprem sonrasında yapılan bir çalışma kapsamında mağdurlarla yapılan anketlerin sonuçları değerlendirilmiş ve geçici barınak/konut için tasarım ölçütleri belirlenmiştir. Geçici konutlarda alan yetersizliği, kalabalık, gürültü ve hijyen sıkıntılarının sorunların başında geldiği saptanmış, çözüm önerilerinin mağdurların psikolojik gereksinimleri ve mahremiyet arayışlarıyla bağlantılı olduğu ortaya çıkmıştır. Barınak veya geçici konut değil, bir 'ev'e olan gereksinim belirlenmiş ve tasarım kıstasları incelenmiştir.

BELMA YÜKSEL, B. Design,

Received her bachelor degree from the Department of Interior Architecture and Environmental Design in İzmir University of Economics, and is currently a research assisstant at Yaşar University, Department of Interior Architecture. Research interest is in earthquake resistant spatial design and design programming regarding spaces for children.

DENIZ HASIRCI; B.Arch., M.Arch., Ph.D.

Is the Head of the Department of Interior Architecture and Environmental Design, İzmir University of Economics. A Fulbright scholar, she has published in the journals Creative Behavior, Creativity Research Journal, Arkitekt, Düşe-Yazma, Patika and Koridor.

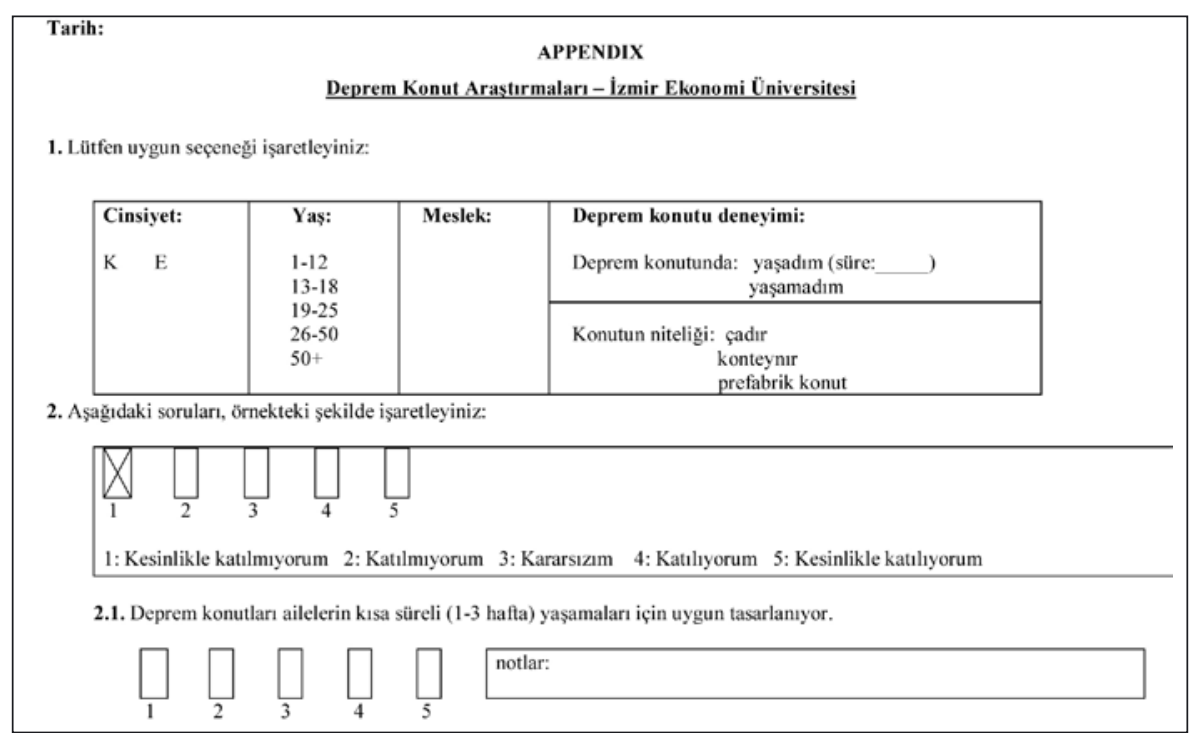


2.2. Deprem konutları ailelerin uzun süreli ( 1 ay-2 yıl) yaşamaları için uygun tasarlanıyor.
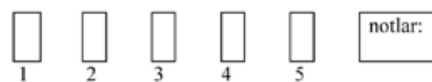

2.3. Deprem konutlarının tasarımında aile üyesi sayısına dikkat ediliyor.

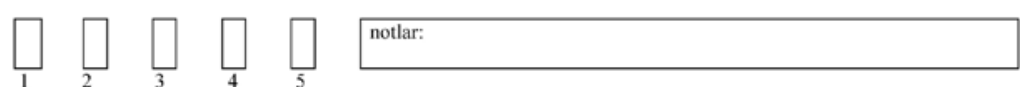

2.4. Deprem konutlarının tasarımında aile üyelerinin psikolojik durumuna önem veriliyor.

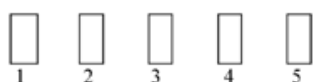

notlar:

2.5. Deprem konutlarının tasarımında aile üyelerinin mahremiyet duygusuna önem veriliyor.

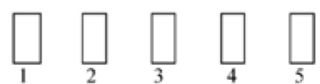

notlar:

3. Ülkemizdeki deprem konutlarını en büyük sorunu:

4. Ülkemizdeki deprem konutlarının en basarıh örnẹ̆i

5. Deprem konutlarının iyileștirilebilmesi için önerilerinizi yazınız:

Deprem Konut Arastırmaları - Izmir Ekonomi Û̃niversitesi

Deprem Konutu "Mahremiyet" Araştırması

1. Konut istediğinizde yalnız kalmanıza olanak sağlıyor.

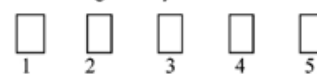

\section{notlar:}

2. Konut özel konuşmalarınızı rahatça yapabilmek için mekânsal olanak sağlıyor.

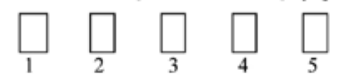

3. Konut içinde görsel mahremiyet için konut içinde paneller/ engeller var.

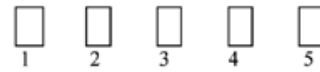

notlar:

4. Konutun kalabalık olduğu hissiyatı olușmuyor.

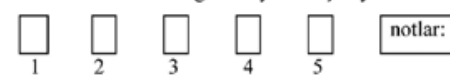

5. Kişisel işlerinizi yaparken dikkatinizi toplayabiliyorsunuz.

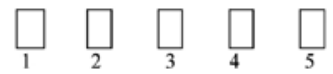

6. Konutu dilediğiniz șekilde kișiselleștirebiliyorsunuz

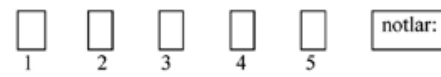

7. Konutun size ait olduğunu hissediyorsunuz.

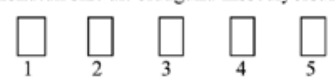

8. Konut içindeki mobilyalarla ilgili seçenekleriniz olduğunu hissediyorsunuz

$\square \square_{1} \square_{3} \square_{4} \square_{5}$ notlar:

